\title{
FAKTOR-FAKTOR YANG MEMENGARUHI NIAT MEMBELI MAKANAN KEMASAN BERLABEL HALAL LPPOM-MUI
}

\author{
Maghfiroh \\ Universitas Negeri Yogyakarta, Indonesia \\ Email:maghfirohalhabsy@gmail.com
}

\begin{abstract}
Abstrak: Faktor-faktor yang Memengaruhi Niat Membeli Makanan Kemasan Berlabel Halal LPPOM-MUI. Penelitian ini bertujuan untuk mengetahui pengaruh faktor personal, faktor sosial, faktor informasi dan sikap terhadap niat membeli produk makanan kemasan berlabel halal LPPOM-MUI pada mahasiswa nonmuslim UNY baik secara parsial maupun simultan. Penelitian ini termasuk penelitian kausal asosiatif yang meneliti pengaruh hubungan variabel bebas dan variabel terikat. Populasi penelitian adalah mahasiswa S-1 nonmuslim di UNY tahun 2011-2014. Sampel penelitian berjumlah 92 mahasiswa dengan menggunakan metode purposive sampling. Pengumpulan data dilakukan dengan angket, analisis data mengunakan metode regresi probit. Hasil penelitian menunjukkan dari 4 variabel bebas terdapat 3 variabel yang tidak berpengaruh. Variabel yang tidak berpengaruh tersebut yaitu variabel faktor personal, sosial, informasi sedangkan variabel yang berpengaruh yaitu variabel sikap. Secara simultan terdapat pengaruh faktor personal, sosial, informasi dan sikap terhadap niat membeli makanan kemasan berlabel halal LPPOM-MUI pada mahasiswa nonmuslim UNY.
\end{abstract}

Kata kunci: niat membeli, personal, sosial, informasi, sikap

\begin{abstract}
The Determinants of Intention to Buy Labeled Halal Foods By LPPOM-MUI. This study aims to investigate the effect of personal, social, information factors and attitudes on the intention to buy packed labeled halal food products by LPPOM-MUI among non-Muslim students of Yogyakarta State University. This was an associate causal study investigating the effects of independent variables on a dependent variable. The sample, consisting of 92 students was selected by means of the purposive sampling technique. The data were collected through a questionnaire and were analyzed using the probit regression method. The results showed of four independent variables, three of them had no effect on independent variable. Those three variables were personal, social, and information. Simultaneously there was an influence of personal, social, information and attitude variables toward the intention of buying packaged labeled halal food by LPPOM-MUI on non-Muslim students of Yogyakarta State University.
\end{abstract}

Keywords: intention to buy, personal, social, information, attitude

\section{PENDAHULUAN}

Badan Pusat

memproyeksikan

Statistik

nasional

jumlah penduduk

Indonesia pada tahun 2015 yaitu sekitar 255

juta jiwa. Adapun Islam adalah agama yang

paling banyak dianut di Indonesia atau sekitar $87 \%$ jumlah penduduk Indonesia menganut agama Islam (BPS 2010). Perilaku sebagai seorang yang menganut agama Islam (muslim) telah diatur dalam Al-quran termasuk di dalamnya perilaku dalam mengkonsumsi makanan. Kehalalan sebuah 
makanan merupakan suatu hal yang sangat mendasar bagi umat Islam.

Menurut kepala Badan Standardisasi Nasional (BSN) Bambang Prasetya mengatakan Indonesia sangat jauh tertinggal dari Malaysia dalam hal standar halal. Dari total produk yang diperdagangkan di Tanah Air, baru 20\% yang berlabel halal, sedangkan di Malaysia sudah di atas $90 \%$. (www.tribunnews.com). Kelebihan makanan halal ini mengilhami nonmuslim di luar negeri untuk lebih antusias terhadap produk halal. Di Inggris misalnya, daging halal meningkatkan penjualan hingga $11 \%$, padahal jumlah penduduk muslim yang ada hanya mencapai $3 \%$ dari seluruh penduduk Inggris. Hal ini disebabkan oleh persepsi kesegaran dan kebersihan produk halal. (Market Brief ITPC Osaka, 2013: 16 ).

Lalu bagaimana dengan nonmuslim di UNY khususnya mahasiswa nonmuslimnya? Apakah mahasiswa nonmuslim di UNY tertarik pada makanan halal? Maka hal inilah yang mendasari peneliti untuk melakukan penelitian. Berdasarkan observasi lebih mendalam peneliti yaitu atas tidak kesengajaan/kebetulan. Faktor kedua adalah preferensi/selera konsumen dalam memilih suatu merek produk tertentu, biasanya konsumen nonmuslim membeli produk makanan kemasan berlabel halal LPPOMMUI karena mereka menyukai merek produk tertentu yang kebetulan telah mendapat sertifikasi halal.

Berdasarkan latar belakang diatas ditemukan masalah terkait makanan kemasan berlabel halal yaitu pertama, pencantuman label halal masih bersifat suka rela karena faktor regulasi yang membutuhkan biaya. Kedua, banyak produsen nakal yang mencantumkan label halal yang tidak terstandarisasi tanpa diketahui keabsahan label halal tersebut. Ketiga, produk di Indonesia yang berlabel halal LPPOM-MUI masih sekitar 20\% dari total produk yang beredar di Indonesia. Keempat, di luar negeri yang mayoritas penduduk nonmuslim lebih antusias terhadap produk halal sedangkan di Indonesia masih belum diketahui. permasalahan di luar negeri yang mayoritas penduduk nonmuslim lebih antusias terhadap produk halal sedangkan di Indonesia dan khususnya UNY masih belum diketahui.

Dalam penelitian ini menggunakan Theory Planned Behavior (TPB) sebagai teori utama. Ajzen (2002) mengemukakan bahwa Theory of Planned Behavior telah muncul sebagai salah satu dari kerangka kerja yang paling berpengaruh dan konsep yang populer pada penelitian di bidang kemanusiaan. Teori ini berusaha untuk memprediksi dan menjelaskan perilaku manusia dalam konteks tertentu. Dalam teori perilaku terencana (Theory of Planned Behavior), faktor utama dari suatu perilaku yang ditampilkan individu adalah intensi untuk menampilkan perilaku tertentu (Ajzen, 1991: $5)$.

Intensi diasumsikan sebagai faktor motivasional yang mempengaruhi perilaku. Intensi merupakan indikasi seberapa keras seseorang berusaha atau seberapa banyak usaha yang dilakukan untuk menampilkan suatu perilaku. Sebagai aturan umum, semakin keras intensi seseorang untuk terlibat dalam suatu perilaku, semakin besar kecenderungan ia untuk benar-benar melakukan perilaku tersebut. Intensi untuk 


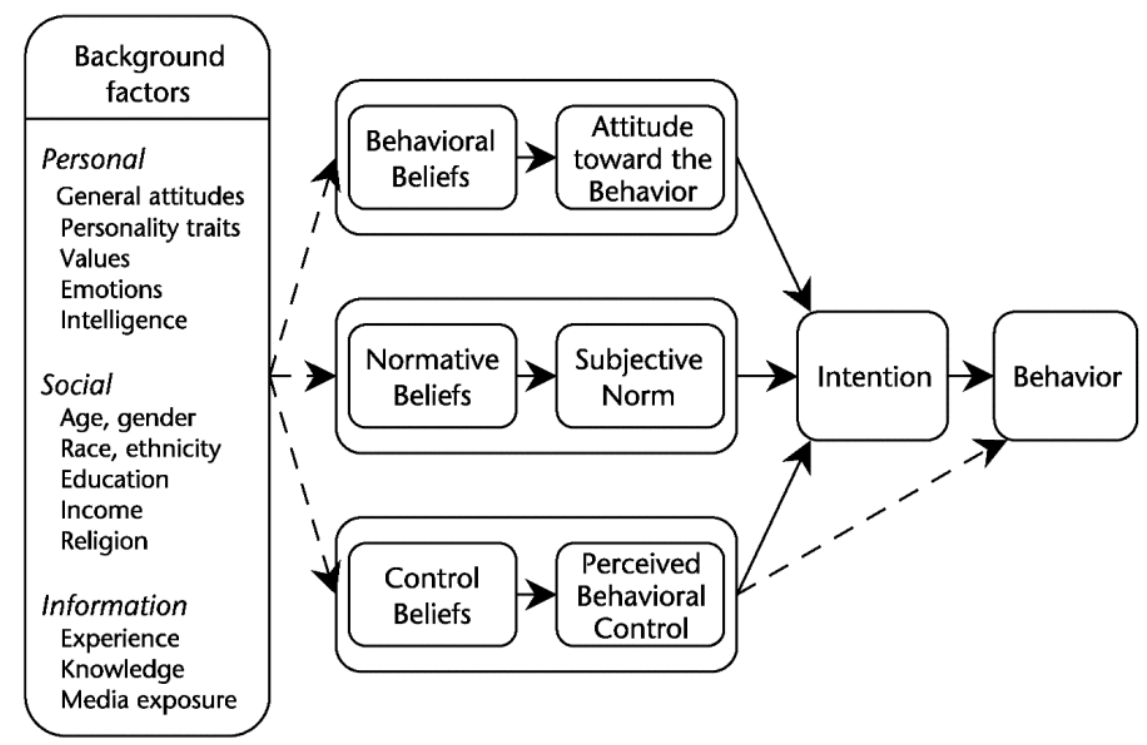

Gambar 1. Model Theory Planned Behavior

Sumber : Theory Of Planned Behavior, Ajzen (2005)

berperilaku dapat menjadi perilaku sebenarnya hanya jika perilaku tersebut ada di bawah kontrol individu yang bersangkutan. Individu memiliki pilihan untuk memutuskan perilaku tertentu atau tidak sama sekali (Ajzen, 1991: 6).

Niat pembelian yang dimiliki konsumen berasal dari sikap dan penilaian konsumen terhadap suatu produk serta faktor-faktor eksternal dari produk tersebut. Sikap, penilaian, serta faktor faktor eksternal lainnya ini merupakan faktor yang snagat penting untuk memprediksi perilaku konsumen (Fishbein dan Aizen 1975). Niat pembelian dapat mengukur seberapa besar kemungkinan konsumen dalam membeli sebuah produk, dimana semakin tinggi niat pembeliannya semakin tinggi niat konsumen untuk membeli produk tersebut (Dodds, et al, 1991; Schiffman dan Kanuk, 2000)

Niat membeli makanan kemasan berlabel halal LPPOM-MUI pada mahasiswa nonmuslim di UNY masih belum diketahui meskipun keberadaan mahasiswa nonmuslim sedikit yang jumlahnya menjadi bagian dari minoritas yang hidup berdampingan dengan mahasiswa muslim. Oleh karena itu perlu diketahui faktor pengaruh yang mempengaruhi niat mahasiswa nonmuslim di UNY dalam membeli makanan kemasan berlabel halal LPPOM-MUI. Manfaat penelitian ini yang pertama adalah penelitian ini dapat dijadikan sebagai sumber pengetahuan dan sebagai aplikasi praktis ilmu yang diperoleh peneliti dibangku kuliah. Yang kedua adalah sebagai sebuah karya yang dapat dijadikan bahan wacana dan pustaka bagi mahasiswa yang memiliki ketertarikan meneliti dibidang yang sama.

\section{METODE}

Dilihat dari tujuan penelitian, penelitian ini termasuk penelitian terapan dan berdasarkan tingkat eksplanasinya penelitian ini termasuk ke dalam penelitian assosiatif kausal karena mencari pengaruh variabel bebas terhadap variabel terikat (Sugiyono, 2013). Penelitian ini dilakukan di Universitas Negeri Yogyakarta yang beralamatkan di 
Jalan Colombo No. 1 Yogyakata. Penelitian ini dilakukan pada bulan Januari - September 2015.

Populasi dalam penelitian ini adalah seluruh mahasiswa nonmuslim (Kristen, Katholik, Hindu, Buddha) di UNY angkatan 2011 sampai 2014 yang berjumlah 1233 mahasiswa. Populasi Mahasiswa Nonmuslim UNY 2011 - 2014. Sampel yang digunakan dalam penelitian ini menggunakan metode purposive sampling dan dengan menggunakan rumus sampel menurut pendapat dari Taro Yamane atau Slovin didapat sampel sebanyak 92 mahasiswa.

Pada penelitian ini menggunakan skala Guttman pada variabel $Y$ yaitu variabel niat membeli produk makanan kemasan berlabel halal. Menurut Sugiyono (2013:139) Skala pengukuran dengan tipe ini akan didapat jawaban yang tegas. Data yang diperoleh dapat berupa data interval atau rasio dikotomi (dua alternatif) dengan kriteria setuju diberi skor 1 dan tidak setuju diberi skor 0.

Untuk mengukur variabel bebas faktor personal, faktor sosial, faktor informasi dan sikap digunakan skala Likert. Skala Likert digunakan untuk mengukur sikap, pendapat, dan persepsi seseorang atau sekelompok orang tentang fenomena sosial. Dengan skala Likert variabel yang akan diukur dijabarkan menjadi indikator variabel. Jawaban setiap instrumen yang menggunakan skala Likert mempunyai gradasi dari sangat positif sampai sangat negatif dengan skor 1-4.

Indikator untuk masing-masing variabel yaitu indikator untuk variabel personal yaitu nilai dan kepribadian, indikator variabel sosial yaitu usia kepercayaan, penghasilan, indikator variabel informasi pemberitaan media massa dan pengetahuan dalam penelitian ini alat ukur pengetahuan yang digunakan yaitu test.

Dalam memperoleh data yang diinginkan, penelitian ini menggunakan teknik pengumpulan data dengan menggunakan data subjek dan data fisik. Data subjek adalah data berupa opini, sikap, pengalaman atau karakteristik dari seseorang atau kelompok orang yang menjadi subjek penelitian (responden). Data ini berbentuk tanggapan (respon) secara lisan dan tertulis yang diberikan melalui pertanyaan tertulis (kuesioner) yang diajukan oleh peneliti. Kuesioner (angket), kuesioner merupakan teknik pengumpulan data dengan cara membagikan sejumlah kuesioner kepada pihak-pihak yang bersangkutan dalam penelitian. (Syofian Siregar: 2011: 124). Sedangkan data fisik adalah data dokumentasi berupa buku, catatan, jurnal, majalah, dokumen, catatan harian dan hal lainnya yang mendukung untuk penelitian.

Penelitian ini menggunakan beberapa teknik analisis data yang pertama adalah menggunakan teknik analisis statistika deskriptif yaitu membahas beberapa hal terkait rata - rata (mean), standar deviasi, nilai maksimum, nilai minimum, dan jumlah data penelitian, frekuensi data dan kecenderungan data.

Teknik analisis yang kedua adalah teknik analisis probit. Model probit ini digunakan untuk menganalisis model dengan variabel dependen yang memiliki hasil binary yaitu y = 1 untuk menandakan suksesnya sebuah kejadian, $y=0$ untuk menandakan gagalnya sebuah kejadian. Teknik analisis yang ketiga yaitu model fit dengan menggunakan cara 
Tabel 1. Hasil Probit Regression

\begin{tabular}{c|c|c|c|c}
\hline Variabel & Koefisien & Standar Error & Z-statistic & $\mathrm{p}>|\mathrm{z}|$ \\
\hline Faktor Personal (X1) & $-0,046$ & 0,061 & $-0,75$ & 0,451 \\
Faktor Sosial (X2) & $-0,050$ & 0,057 & $-0,88$ & 0,380 \\
Faktor Informasi (X3) & 0,032 & 0,023 & 1,39 & 0,166 \\
Sikap (X4) & 0,244 & 0,053 & 4,53 & 0,000 \\
\hline Konstanta & $-8,564$ & 2,490 & $-3,44$ & 0,001 \\
\hline Log likehood & $-45,490291$ & & & \\
LR chi2(4) & 32,18 & & & \\
Prob > chi2 & 0,0000 & & & \\
Pseudo R2 & 0,2613 & & & \\
\hline
\end{tabular}

goodness of fit test. Pengujian goodness of fit ini dengan berdasarkan specificity, sensitivity dan correctly classification. Nilai sensitivity merupakan keakuratan model dalam membaca kejadian sukses yang dinyatakan dengan benar sebagai kejadian sukses dari keseluruhan observasi dalam model. Nilai specificity yaitu keakuratan model dalam membaca kejadian tidak sukses sebagai kejadian tidak sukses dari keseluruhan observasi di dalam model. Nilai correctly classification menggambarkan keakuratan model secara keseluruhan. Teknik analis yang keempat yaitu Marginal Effect. Marginal effect merupakan nilai perubahan pada masing - masing variabel. Dalam pengujian marginal effect dilakukan pengujian tanda untuk mengetahui apakah variabel bebas memberikan efek positif atau negatif terhadap variabel terikat. Pengujian ini dilihat dari tanda koefisien variabel bebas, tanda tersebut dapat positif maupun negatif.

\section{HASIL DAN PEMBAHASAN}

Tabel 1 menerangkan bahwa nilai $p>|z|$ menunjukkan taraf signifikansi. Pada penelitian ini menggunakan taraf signifikansi sebesar $5 \%$ atau sama dengan 0,05 jika nilai taraf signifikansi variabel lebih dari 0,05 menandakan variabel bebas tersebut tidak berpengaruh terhadap variabel terikat. Dalam model regresi biner pseudo $\mathrm{R}^{2}$ mirip dengan $\mathrm{R}^{2}$, yang berfungsi untuk mengukur goodness of fit. Prob $>$ chi $=0,0000$ menunjukkan nilai pengaruh variabel bebas terhadap variabel terikat secara simultan.

Secara umum dari hasil uji regresi probit tersebut diketahui taraf signifikansi dari 4 variabel bebas yang digunakan terdapat 3 variabel yang tidak berpengaruh terhadap niat membeli makanan kemasan berlabel halal LPPOM-MUI pada mahasiswa nonmuslim di UNY dan 1 variabel yang berpengaruh. Variabel yang tidak berpengaruh tersebut yaitu faktor personal, faktor sosial dan faktor informasi. Sedangkan variabel yang berpengaruh terhadap niat membeli makanan kemasan berlabel halal LPPOM-MUI pada mahasiswa nonmuslim di UNY yaitu sikap konsumen.

Tahap selanjutnya setelah mengetahui probabilitas variabel bebas terhadap variabel terikat yaitu mengetahui marginal effect yaitu nilai perubahan masing - masing variabel bebas terhadap variabel terikat yang akan disajikan dalam Tabel 2. 
Tabel 2. Hasil Estimasi Marginal Effect

\begin{tabular}{c|c|c|c}
\hline Variabel & Koefisien & Standard error & Z-statistic \\
\hline Faktor Personal & -0.017 & 0,023 & $-0,75$ \\
Faktor Sosial & -0.018 & 0,021 & $-0,88$ \\
Faktor Informasi & 0,012 & 0,008 & 1,39 \\
Sikap & 0,091 & 0,020 & 4,46 \\
\hline
\end{tabular}

Dari hasil uji marginal effect dapat diketahui bahwa nilai koefisien, Standard error dan Z-statistic. Nilai koefisien menunjukkan besarnya pengaruh setiap satuan kenaikan atau penurunan variabel bebas terhadap variabel terikat, nilai Zstatistic adalah signifikansi suatu koefisien secara statistik (distribusi normal).

Adapun hasil pengujian marginal effect didapat koefisien faktor personal sebesar 0,017 yang mengimplikasikan setiap kenaikan faktor personal pada kategori sangat baik akan mengurangi niat membeli makanan kemasan berlabel halal LPPOMMUI mahasiswa nonmuslim sebesar $17 \%$, koefisien faktor sosial sebesar $-0,018$ mengimplikasikan setiap kenaikan faktor sosial pada kategori sangat baik akan mengurangi niat membeli makanan kemasan berlabel halal LPPOM-MUI mahasiswa nonmuslim sebesar 18\%, koefisien faktor informasi sebesar 0,012 mengimplikasikan setiap kenaikan faktor informasi pada kategori sangat baik akan meningkatkan niat membeli makanan kemasan berlabel halal LPPOM-MUI mahasiswa nonmuslim sebesar $12 \%$ akan tetapi berdasarkan pengujian regresi probit ketiga factor tersebut tidak berpengaruh terhadap niat membeli makanan kemasan berlabel halal LPPOMMUI pada mahasiswa nonmuslim di UNY. Sedangkan pada pengujian regresi probit sikap menunjukkan terdapat pengaruh sikap terhadap niat membeli makanan kemasan berlabel halal LPPOM-MUI pada mahasiswa nonmuslim di UNY adapun nilai marjinal effect sikap yaitu sebesar 0,091 yang artinya setiap peningkatan sikap mahasiswa nonmuslim UNY pada kategori sangat baik maka dapat meningkatkan niat membeli makanan kemasan berlabel halal LPPOMMUI sebesar 91\%.

Peneliti menemukan temuan mengapa variabel faktor personal tidak berpengaruh yaitu Hasil kuesioner menunjukkan meskipun responden lebih banyak menjawab setuju dengan konsep makanan kemasan berlabel halal yang mengutamakan kebersihan, dan keamanan produk tetapi hal itu tidak mendorong mereka untuk sampai berniat membeli makanan kemasan berlabel halal MUI hal tercermin pada jawaban responden yang mayoritas menjawab bahwa membeli makanan kemasan berlabel halal LPPOM MUI bukan sesuatu yang penting.

Untuk mengukur variabel faktor sosial digunakan indikator usia, kepercayaan, dan penghasilan. Hasil kuesioner menunjukkan meskipun mereka lebih banyak menjawab setuju bahwa makanan kemasan berlabel halal LPPOM-MUI menyediakan produk untuk usia mereka saat ini, kepercayaan yang mereka anut tidak menghalangi mereka untuk mengkonsumsi makanan kemasan berlabel halal LPPOM-MUI, penghasilan mereka memungkinkan mereka membeli produk makanan kemasan berlabel halal LPPOM-MUI meskipun harganya lebih mahal 
dari produk lain yang sejenis tetapi hal itu tidak membuat mereka untuk berniat membeli makanan kemasan berlabel halal LPPOM-MUI. Peneliti menemukan faktor lain yang menyebabkan responden membeli makanan kemasan berlabel halal LPPOM MUI, faktor tersebut yaitu responden cenderung membeli makanan kemasan berlabel halal LPPOM MUI karena faktor selera responden pada produk tertentu yang telah berlabel halal.

Dalam penelitian variabel faktor informasi, informasi tentang makanan kemasan berlabel halal yang dimiliki nonmuslim dan muslim tentunya berbeda. Seperti penemuan dilapangan mengatakan pengetahuan/pemahaman tentang label halal pada mahasiswa nonmuslim kurang meskipun di media massa ada berita terkait label halal maupun tentang isu-isu makanan halal. Hal ini tercermin pada hasil kuesioner tes pengetahuan tentang label halal banyak responden yang pengetahuan tentang label halal masih rendah. Adapun kuesioner pengaruh pemberitaan media massa menunjukkan meskipun mereka mengetahui iklan makanan kemasan berlabel halal melalui iklan di media iklan hal itu tidak mempengaruhi mereka untuk membeli makanan kemasan berlabel halal LPPOMMUI.

Berdasarkan penelitian yang telah dilakukan sikap berpengaruh positif dan signifikan terhadap niat membeli makanan kemasan berlabel halal LPPOM-MUI pada mahasiswa nonmuslim di UNY. Semakin baik sikap yang ditunjukan individu responden mendukung dalam membeli makanan kemasan berlabel halal MUI, maka kemungkinan mahasiswa nonmuslim UNY untuk berniat membeli makanan kemasan berlabel halal LPPOM-MUI akan semakin tinggi. Hal ini sesuai dengan teori yang dikemukakan oleh Ajzen Sikap terhadap suatu perilaku (attitude toward behavior) ditentukan oleh keyakinan terhadap suatu perilaku (behavior beliefs) dan biaya atau keuntungan dari perilaku tersebut (Ajzen, 1991). Sikap yang dimaksud termasuk perasaan tentang sesuatu yang ingin dicapai dari perilaku yang dia lakukan (Sharma et. al., 2003). Sikap merupakan pernyataan atau pertimbangan evaluatif mengenai objek, orang, atau peristiwa (Robin, 1998). Sikap biasanya memainkan peran utama dalam membentuk perilaku. Sikap juga dipandang sebagai keseluruhan evaluasi (Engel et. al.,1995). Berdasarkan hasil diatas dapat disimpulkan bahwa semakin baik sikap yang ditunjukkan oleh responden maka niat untuk membeli makanan kemasan berlabel halal LPPOM-MUI semakin meningkat.

Berdasarkan hasil penelitian faktor personal, faktor sosial, faktor informasi dan sikap secara bersama - sama berpengaruh terhadap niat membeli makanan kemasan berlabel halal LPPOM-MUI. Hal ini sesuai yang dikemukakan oleh Ajzen bahwa Seperti usia, jenis kelamin, suku, status sosial ekonomi, suasana hati, sifat kepribadian, dan pengetahuan mempengaruhi sikap dan perilaku individu terhadap sesuatu hal. Faktor personal, faktor sosial, faktor informasi (faktor latar belakang) pada dasarnya adalah sifat yang hadir di dalam diri seseorang, yang dalam model Kurt Lewin dikategorikan ke dalam aspek O (organism). Dalam kategori ini Ajzen (2005:135). Faktor personal adalah sikap umum seseorang terhadap sesuatu, sifat kepribadian 
(personality traits), nilai hidup (values), emosi, dan kecerdasan yang dimilikinya. Faktor sosial antara lain adalah usia, jenis kelamin (gender), etnis, pendidikan, penghasilan, dan agama. Faktor informasi adalah pengalaman, pengetahuan, dan pemberitaan media massa. Perilaku yang spesifik oleh persepsi bias keyakinan berperilaku. sebagai akibatnya mereka dapat mempengaruhi sikap terhadap perilaku, niat kemudian tindakan.

\section{SIMPULAN}

Dari 4 variabel bebas yang digunakan terdapat 3 variabel yang tidak berpengaruh terhadap niat membeli makanan kemasan berlabel halal LPPOM-MUI pada mahasiswa nonmuslim di UNY dan 1 variabel yang berpengaruh. Variabel yang tidak berpengaruh tersebut yaitu faktor personal, faktor sosial dan faktor informasi. Sedangkan variabel yang berpengaruh terhadap niat membeli makanan kemasan berlabel halal LPPOM-MUI pada mahasiswa nonmuslim di UNY yaitu sikap konsumen.

Temuan tersebut mengandung implikasi bahwa untuk mahasiswa nonmuslim membeli makanan kemasan berlabel halal LPPOM-MUI bukanlah sesuatu yang salah, karena konsep makanan halal sendiri selain tidak mengandung babi atau hewan yang dilarang dalam islam yaitu makanan harus bebas dari zat yang membahayakan tubuh, makanan harus bersih dan hal ini berarti konsep seperti itu tidak hanya berlaku pada mahasiswa muslim tetapi juga bisa berlaku untuk mahasiswa nonmuslim. Mahasiswa nonmuslim di UNY secara tidak sadar seharihari mengkonsumsi produk makanan kemasan berlabel halal LPPOM-MUI, namun pada angket penelitian mereka lebih banyak menjawab tidak setuju untuk itu perlu diberi arahan bahwa sebagian besar makanan kemasan telah berlabel halal LPPOM-MUI.

\section{DAFTAR PUSTAKA}

Ajzen \& Fishbein. (1975) Beliefs, Attitudes, Intention And Behavior: An Introduction To Theory And Research. Philippines: Addision Wesley.

Ajzen. I. (1991) The Theory of Planned Behaviour. Organizational Behaviour and Human Decision Process. Amherst, MA: Elsevier, 50: $179-211$.

BPS. (2010) Jumlah penduduk Indonesia menurut survei penduduk tahun 2010. Diakses tanggal 23 Februari 2015 dari www.bps.go.id

Market Brief ITPC Osaka. (2013) Journal Product Halal. halaman 16

Schiffman, Leon G. \& Kanuk, Leslie Lazar. (2000) Consumer Behavior. Prentice: Hall International.

Siregar Syofian. (2011) Statistika Deskriptif untuk Penelitian. RajaGrafindo Persada: Jakarta.

Sugiyono. (2010) Metode Penelitian Pendidikan Pendekatan Kuantitatif, Kualitatif, dan $R \& D$. Bandung: Alfabeta.

Sugiyono. (2013) Metode Penelitian Bisnis. Bandung: Alfabeta.

Tribun. (2015) Total produk halal di Indonesia. Tribun News. Diakses pada 8 Februari 2015 dari www.tribunnews.com 